\title{
Analisis Kebutuhan Bahan Ajar Booklet Bangun Datar dan Sifat-sifatnya untuk Siswa Sekolah Dasar/Madrasah Ibtidaiyah
}

\author{
Siti Nur Rohmah', Yuniawatika², Suhel Madyono ${ }^{3}$ \\ 1,2,3Universitas Negeri Malang, Indonesia \\ 1siti.nur.1601516@students.um.ac.id, 2yuniawatika.fip@um.ac.id, 3suhel-madyono@fip.um.ac.id
}

DOI: $10.18860 / \operatorname{mad} . v 12 \mathrm{i} 2.8927$

Abstract. This study aims to present the results of a needs analysis teaching material booklet flat build and its characteristics in class III B MI Qomarul Hidayah Trenggalek students. This research is descriptive research. The data were obtained from interviews with class III B MI Qomarul Hidayah Trenggalek teachers, the results of the documentation, and the results of a needs analysis questionnaire filling by 15 students of class III B MI Qomarul Hidayah Trenggalek in 2019/2020 academic year. From the results of a needs analysis questionnaire, it was obtained that students in class III B MI Qomarul Hidayah Trenggalek 86,7\% needed teaching materials that had practical size, $93,3 \%$ needed additional learning resources about flat build and its characteristics more complete material, 93,3\% needed practice exercises to measure understanding of the material flat build and its characteristics, 93,3\% needed teaching materials that could be used for independent learning, and 100\% agreed if booklet flat build and its characteristics were developed. It can be concluded that students of class III B MI Qomarul Hidayah Trenggalek agreed if booklet flat build and its characteristics were developed. The booklet developed was adjusted to the results of interviews with class III B MI Qomarul Hidayah Trenggalek teachers, the results of the documentation, as well as the results of filling the needs analysis questionnaire of students class III B MI Qomarul Hidayah Trenggalek namely: having a practical size, more complete material, there were exercises, and can be used for independent learning.

Keywords. Needs Analysis; Teaching Materials; Booklet; Flat Build and Its Characteristics

Abstrak. Penelitian ini bertujuan untuk mengemukakan hasil analisis kebutuhan bahan ajar booklet bangun datar dan sifat-sifatnya siswa kelas III B MI Qomarul Hidayah Trenggalek. Penelitian ini merupakan penelitian deskriptif. Data dalam penelitian ini diperoleh dari hasil wawancara dengan guru kelas III B MI Qomarul Hidayah Trenggalek, hasil dokumentasi, dan hasil pengisian angket analisis kebutuhan oleh 15 siswa kelas III B MI Qomarul Hidayah Trenggalek tahun pelajaran 2019/2020. Dari hasil pengisian angket analisis kebutuhan diperoleh hasil yaitu siswa kelas III B MI Qomarul Hidayah Trenggalek 86,7\% membutuhkan bahan ajar yang memiliki ukuran praktis, 93,3\% membutuhkan sumber belajar tambahan tentang bangun datar dan sifat-sifatnya yang materinya lebih lengkap, 93,3\% membutuhkan latihan soal untuk mengukur pemahaman terhadap materi bangun datar dan sifat-sifatnya, 93,3\% membutuhkan bahan ajar yang bisa dipakai untuk belajar mandiri, dan $100 \%$ setuju jika dikembangkan booklet bangun datar dan sifat-sifatnya. Dengan demikian dapat disimpulkan bahwa siswa kelas III B MI Qomarul Hidayah Trenggalek setuju jika dikembangkan booklet bangun datar dan sifat-sifatnya. Booklet yang dikembangkan disesuaikan dengan hasil wawancara dengan guru kelas III B MI Qomarul Hidayah Trenggalek, hasil dokumentasi, serta hasil pengisian angket analisis kebutuhan siswa kelas III B MI Qomarul Hidayah Trenggalek yaitu: memiliki ukuran yang praktis, materi lebih lengkap, terdapat latihan soal, dan bisa dipakai untuk belajar mandiri.

Kata kunci. Analisis Kebutuhan; Bahan Ajar; Booklet; Bangun Datar dan Sifat-sifatnya

Received: 08-03-2020

Approved: 15-06-2020

Revised: 05-06-2020

Published: $-06-2020$

Vol. 12 No. 2 Juni 2020

Madrasah homepage: http://ejournal.uin-malang.ac.id/index.php/madrasah/index 


\section{MADRASAH}

Jurnal Pendidikan dan Pembelajaran Dasar

p ISSN: 1979-5599 | e ISSN: 2502-194X

P a g e | 107

Copyright ( $)$ Madrasah Jurnal Pendidikan dan Pembelajaran Dasar. All Right Reserved.

This is an open access article under the CC BY-NC-ND license

(http://creativecommons.org/licenses/by-nc-nd/4.0/).

Correspondence Address: yuniawatika.fip@um.ac.id

\section{A. PENDAHULUAN}

Proses pembelajaran tidak terlepas dari bahan ajar. Bahan ajar merupakan seperangkat materi pelajaran yang merujuk pada kurikulum yang sedang dipakai untuk mencapai SK dan KD yang telah ditetapkan (Lestari (dalam Nurdyansyah, 2018)). Menurut Nurdyansyah (2018) penggunaan bahan ajar bagi guru yaitu sebagai panduan untuk mengetahui kegiatan apa yang harus dilakukan dan materi apa yang harus diberikan kepada siswa dalam proses pembelajaran. Sedangkan bagi siswa yaitu sebagai panduan untuk mengetahui materi apa yang harus dipelajari selama proses pembelajaran. Oleh karena itu bahan ajar memiliki peran penting dalam proses pembelajaran. Bahan ajar yang dipakai siswa haruslah bahan ajar yang baik dan bisa untuk belajar mandiri. Menurut Furqon (dalam Nurdyansyah, 2018) beberapa kriteria bahan ajar yang baik yaitu: (1) materi yang diulas harus benar, lengkap, dan aktual; serta (2) sistematika penyusunan bahan ajar harus jelas, runtut, dan mudah dipahami. Sedangkan menurut Hernawan et al. (2012, p. 2) bahan ajar juga bisa dipakai untuk belajar mandiri apabila bahan ajar tersebut disusun secara lengkap. Dengan demikian agar bahan ajar yang disusun menjadi bahan ajar yang baik dan bisa dipakai untuk belajar mandiri, maka harus memuat materi yang benar, lengkap, dan aktual serta penyusunannya harus jelas, runtut, dan mudah dipahami.

Struktur bahan ajar tersusun atas sejumlah komponen. Setiap jenis bahan ajar memiliki komponen yang berbeda. Untuk bahan ajar jenis buku terdiri dari lima komponen yaitu: (1) judul; (2) kompetensi dasar/materi pokok; (3) informasi pendukung; (4) latihan; dan (5) penilaian (Prastowo, 2016, p. 297). Bahan ajar untuk madrasah ibtidaiyah atau sekolah dasar juga memiliki ukuran tertentu yaitu: (1) A4 dengan bentuk huruf vertikal atau landscape, A5 dengan bentuk huruf vertikal atau landscape, atau B5 dengan bentuk huruf vertikal atau landscape, untuk SD/MI kelas 1-3; dan (2) A4 dengan bentuk huruf vertikal atau landscape, A5 dengan bentuk huruf vertikal, atau B5 dengan bentuk huruf vertikal, untuk SD/MI kelas 4-6 (Sitepu, 2015, p. 131).

Salah satu ragam bahan ajar yang bisa dipakai dalam pembelajaran adalah booklet. Hal tersebut sesuai dengan penelitian yang telah dilakukan oleh Rahmatih et al. (2017) yang mengembangkan booklet materi pemupukan berdasarkan kajian potensi dan masalah lokal. Hasil penelitian tersebut mengemukakan bahwa booklet yang dikembangkan dinilai layak sebagai bahan ajar tambahan. Selain dapat digunakan sebagai bahan ajar tambahan, booklet juga memiliki kelebihan-kelebihan. Menurut Gemilang \& Christiana (2016, p. 6) booklet memiliki kelebihan yaitu mudah digunakan untuk belajar mandiri karena memiliki susunan yang sistematis, menarik, dan dilengkapai dengan gambar ilustrasi. Booklet juga bisa menarik minat siswa untuk mempelajari materi didalamnya karena komponen booklet tidak hanya tulisan saja melainkan dilengkapi dengan unsur kegrafikaan lain yang mendukung (Rahmawati, 
2019, p. 458-459). Menurut Yuliana et al. (2019, p. 51) booklet juga memiliki kelebihan yaitu memiliki struktur isi yang lebih ringkas daripada buku serta penyajian dan gambarnya lebih menarik daripada buku.

Kelebihan lain dari booklet yaitu memiliki desain yang menarik dan bersifat informatif sehingga dapat menambah rasa ingin tahu siswa ketika mempelajari materi didalamnya (Wulandari, 2019, p. 66). Selain itu menurut Farkhana et al. (2017, p. 61) dengan adanya booklet membuat siswa merasa senang ketika mengikuti pembelajaran serta memudahkan siswa memahami materi didalamnya karena booklet tersebut memberi gambaran yang nyata terhadap materi yang dipelajari. Notoatmodjo (dalam Bagaray et al., 2016, p. 79) juga menyebutkan salah satu kelebihan dari booklet yaitu penggunaannya praktis karena bisa dipakai kapanpun dan dimanapun. Booklet juga memiliki definisi yang berbeda-beda. Menurut Bly $(2009$, p. 37) booklet merupakan buku berisi tips dan strategi yang berfungsi untuk mengedukasi pembaca dan menyelesaikan masalah. Sedangkan menurut French $(2013$, p. 1) booklet merupakan buku yang dicetak kecil dan memiliki sekitar 32-96 halaman. Selain itu menurut Utomo (2016, p. 3) booklet memiliki komponen yang terdiri dari pendahuluan, isi, dan penutup sehingga menyerupai buku, namun isi dalam booklet disajikan lebih singkat daripada buku. Dengan demikian booklet dapat dikatakan sebagai bahan ajar jenis buku.

Pengembangan bahan ajar sebaiknya disesuaikan dengan kebutuhan. Hal tersebut sesuai dengan pendapat Hernawan et al. (2012, p. 3) bahwa bahan ajar yang baik adalah bahan ajar yang dikembangkan sesuai dengan persyaratan dan kebutuhan yang diperlukan, sehingga materi pelajaran dapat tersampaikan dengan baik dan siswa pun memiliki aktivitas belajar yang baik. Untuk mengetahui bagaimana bahan ajar yang dibutuhkan, maka perlu dilakukan analisis kebutuhan bahan ajar terhadap siswa kelas III B MI Qomarul Hidayah Trenggalek. Hal tersebut sejalan dengan pendapat Suyitno (2017, p. 65) bahwa langkah awal yang dilakukan untuk mengembangkan bahan ajar adalah dengan melakukan analisis kebutuhan, dan dengan dilakukannya analisis kebutuhan tersebut dapat diketahui bagaimana bahan ajar yang sesuai dengan kondisi siswa.

Sebelum melakukan analisis kebutuhan juga dilakukan wawancara dengan guru kelas III B MI Qomarul Hidayah Trenggalek terkait pelaksanaan pembelajaran dan penggunaan bahan ajar. Dari hasil wawancara menunjukkan bahwa masih terdapat permasalahan dalam pelaksanaan pembelajaran maupun penggunaan bahan ajar pada materi bangun datar dan sifat-sifatnya. Setelah itu dilakukan dokumentasi untuk mendapatkan data terkait keterpaduan materi bangun datar dan sifat-sifatnya pada pembelajaran matematika dan penerapannya. Dari hasil dokumentasi menunjukkan adanya kesenjangan antara materi bangun datar dan sifat-sifatnya pada silabus dengan materi bangun datar dan sifat-sifatnya pada bahan ajar buku tematik yang digunakan siswa. Kegiatan wawancara dan dokumentasi tersebut dilakukan untuk mengetahui materi apa yang difokuskan dalam pengembangan bahan ajar yang kemudian dijadikan acuan untuk membuat angket analisis kebutuhan. Hal tersebut sesuai dengan pendapat Nasrulloh \& Ismail (2017, p. 29) bahwa salah satu fase analisis kebutuhan yaitu memprioritaskan kebutuhan yang paling urgen, baik dilaksanakan, dan layak dilakukan. Dari hasil wawancara dan hasil dokumentasi tersebut maka dilakukan analisis kebutuhan bahan ajar terkait materi bangun datar dan sifat-sifatnya. Analisis kebutuhan tersebut dilakukan dengan memberikan angket kepada siswa kelas III B MI Qomarul Hidayah Trenggalek. Hal ini sejalan dengan pendapat Siska (2015, p. 205) 


\section{MADRASAH}

Jurnal Pendidikan dan Pembelajaran Dasar

p ISSN: 1979-5599 | e ISSN: 2502-194X

P a g e | 109

bahwa analisis kebutuhan dapat dilakukan dengan menyebar angket kepada siswa. Hasil analisis kebutuhan tersebut kemudian dijadikan dasar untuk mengembangkan bahan ajar agar sesuai dengan kebutuhan siswa.

\section{B. METODE PENELITIAN}

Penelitian ini merupakan penelitian deskriptif. Dalam penelitian ini ada tiga objek yang diselidiki yaitu guru kelas III, bahan ajar yang digunakan oleh siswa kelas III, dan siswa kelas III B MI Qomarul Hidayah Trenggalek tahun pelajaran 2019/2020 yang berjumlah 15 siswa. Guru kelas III digunakan untuk mendapatkan informasi tentang pelaksanaan pembelajaran di sekolah dan bahan ajar yang digunakan di sekolah. Bahan ajar merupakan objek kedua untuk mendapatkan informasi adanya keterpaduan materi dan penerapannya. Sedangkan siswa kelas III B MI Qomarul Hidayah Trenggalek digunakan untuk mendapatkan informasi mengenai kebutuhan bahan ajar untuk mendukung pelaksanaan pembelajaran. Teknik pengumpulan data yang digunakan dalam penelitian ini yaitu wawancara, dokumentasi, dan angket analisis kebutuhan. Wawancara digunakan untuk mendapatkan data tentang pelaksanaan pembelajaran dan penggunaan bahan ajar di sekolah. Dokumentasi digunakan untuk mendapatkan data tentang keterpaduan materi pembelajaran matematika dan penerapannya. Dokumen yang digunakan mencakup silabus dan bahan ajar yang digunakan. Angket analisis kebutuhan untuk mengetahui hasil persentase skor pengisian angket analisis kebutuhan. Angket analisis kebutuhan dibuat dengan menggunakan skala Guttman yang terdiri dari dua pilihan jawaban yaitu "ya" dan "tidak" (Sugiyono, 2011, p. 139). Angket tersebut dianalisis menggunakan teknik persentase. Persentase untuk setiap kemungkinan jawaban diperoleh dari pembagian frekuensi yang didapat dengan jumlah sampel, kemudian dikali 100. Adapun rumusnya dijelaskan sebagai berikut (Bungin (dalam Munggaran, 2012, p. 72-73)).

$$
\mathrm{P}=\frac{\mathrm{f}}{\mathrm{n}} \times 100 \%
$$

Keterangan:

$\mathrm{P} \quad=$ Persentase

$\mathrm{f} \quad=$ Frekuensi dari setiap jawaban yang dipilih

$\mathrm{n} \quad=$ Jumlah

Selanjutnya persentase yang diperoleh diterjemahkan ke dalam kategori yang disajikan pada tabel B.1 berikut.

Tabel B.1 Kategori Hasil Persentase Angket Analisis Kebutuhan

\begin{tabular}{cc}
\hline Persentase & Kategori \\
\hline $0-1 \%$ & Tidak ada \\
$2-25 \%$ & Sebagian kecil \\
$26-49 \%$ & Kurang dari setengahnya \\
$50 \%$ & Setengahnya \\
$51-75 \%$ & Lebih dari setengahnya
\end{tabular}

Vol. 12 No. 2 Juni 2020

Madrasah homepage: http://ejournal.uin-malang.ac.id/index.php/madrasah/index 


\begin{tabular}{cc}
\hline Persentase & Kategori \\
\hline $76-99 \%$ & Sebagian besar \\
$100 \%$ & Seluruhnya \\
\hline
\end{tabular}

Sumber: Bungin (dalam Munggaran, 2012, p. 73)

Berdasarkan kategorisasi hasil persentase angket analisis kebutuhan pada tabel B.1, pertanyaan yang terdapat dalam angket analisis kebutuhan memiliki kesimpulan jawaban "ya" apabila frekuensi jawaban "ya" pada pertanyaan tersebut memiliki persentase lebih dari sama dengan 50\%. Apabila frekuensi jawaban "ya" pada pertanyan yang terdapat dalam angket analisis kebutuhan memiliki persentase kurang dari 50\%, maka pertanyaan tersebut memiliki kesimpulan jawaban "tidak".

Dalam pengisian angket analisis kebutuhan, siswa didampingi oleh peneliti, hal ini sesuai dengan saran dari Etika et al. (2017, p. 183) bahwa dalam pengisian angket atau kuesioner harus didampingi agar angket atau kuesioner tersebut terisi dengan baik dan benar. Pendampingan ini bertujuan untuk menyampaikan ulang pertanyaanpertanyaan yang terdapat pada angket analisis kebutuhan sesuai dengan bahasa anak agar maksud dari pertanyaan-pertanyaan tersebut mudah diterima oleh siswa serta menghindari pengisian angket secara subyektif. Hal ini sejalan dengan pendapat Fanny \& Suardiman (2013, p. 6-7) bahwa dengan mengubah kata atau kalimat yang terdapat pada angket sesuai dengan tingkat kemampuan pemahaman siswa akan memudahkan siswa dalam mengisi angket tersebut serta menjadikan siswa mengisi angket tersebut secara objektif. Pendampingan ini juga bertujuan untuk memudahkan siswa apabila terdapat siswa yang bertanya terkait pertanyaan-pertanyaan yang menurutnya kurang jelas serta memberi pengantar atau penjelasan berkaitan dengan bahan ajar yang dilakukan sebelum siswa mengisi angket analisis kebutuhan.

\section{HASIL DAN PEMBAHASAN}

Hasil wawancara dengan guru kelas III B MI Qomarul Hidayah Trenggalek terkait pelaksanaan pembelajaran dan penggunaan bahan ajar adalah sebagai berikut: (1) siswa hanya menggunakan bahan ajar cetak berupa buku tematik sebagai sumber belajar; (2) buku tematik memiliki ukuran yang besar; (3) materi di dalam buku tematik tentang bangun datar dan sifat-sifatnya masih terbatas; (4) di dalam buku tematik tidak terdapat latihan soal; (5) siswa hanya mendapat latihan soal hasil download dari internet; (6) siswa yang berkemampuan rendah tidak bisa mengikuti siswa yang berkemampuan sedang dan tinggi; (7) masih banyak siswa yang mengharapkan jawaban dari siswa lain ketika diberi soal; dan (8) belum berkembangnya karakter mandiri dalam diri siswa. Dari hasil wawancara tersebut menunjukkan bahwa masih terdapat permasalahan dalam pelaksanaan pembelajaran maupun penggunaan bahan ajar dalam proses pembelajaran matematika pada materi bangun datar dan sifat-sifatnya.

Hasil dokumentasi menunjukkan adanya kesenjangan antara materi bangun datar dan sifat-sifatnya pada silabus dengan materi bangun datar dan sifat-sifatnya pada bahan ajar buku tematik yang digunakan siswa. Materi tentang bangun datar dan sifat-sifatnya pada silabus memuat pengertian, macam-macam, unsur-unsur, dan sifatsifat bangun datar segi empat, segi tiga, dan lingkaran. Bangun datar segi empat pada silabus mencakup persegi, persegi panjang, belah ketupat, jajar genjang, layang-layang, dan trapesium. Sedangkan bangun datar segi tiga pada silabus mencakup segi tiga sama sisi, segi tiga sama kaki, segi tiga siku-siku, dan segi tiga sembarang. Berbeda 


\section{MADRASAH}

Jurnal Pendidikan dan Pembelajaran Dasar

dengan materi pada buku tematik. Di dalam buku tematik materi tentang bangun datar dan sifat-sifatnya hanya membahas pengertian, macam-macam, unsur-unsur, dan sifatsifat bangun datar segi empat dan segi tiga. Bangun datar segi empat hanya mencakup persegi dan persegi panjang. Sedangkan bangun datar segi tiga hanya mencakup segi tiga sama sisi. Dengan demikian materi bangun datar dan sifat-sifatnya pada buku tematik yang digunakan siswa sebagai bahan ajar masih kurang lengkap karena belum memuat semua materi bangun datar dan sifat-sifatnya yang terdapat pada silabus.

Setelah melakukan wawancara dan dokumentasi, maka dilakukan analisis kebutuhan bahan ajar terkait materi bangun datar dan sifat-sifatnya melalui angket analisis kebutuhan untuk mengetahui bagaimana bahan ajar yang dibutuhkan siswa kelas III B MI Qomarul Hidayah Trenggalek sebagai pendukung pelaksanaan pembelajaran. Angket tersebut terdiri dari 5 pertanyaan. Kesimpulan hasil pengisian angket tersebut dipaparkan sebagai berikut:

1. Siswa kelas III B MI Qomarul Hidayah Trenggalek membutuhkan bahan ajar yang berukuran praktis

Bahan ajar yang digunakan siswa kelas III B MI Qomarul Hidayah hanya berasal dari buku tematik. Buku tematik memiliki ukuran $21 \mathrm{~cm} \times 29,7 \mathrm{~cm}(\mathrm{~A} 4)$. Berdasarkan hasil wawancara dengan guru kelas III B MI Qomarul Hidayah Trenggalek, buku tematik memiliki ukuran yang besar sehingga siswa merasa kesulitan ketika membawa buku tematik tersebut. Menurut Sitepu (2015, p. 131) bahan ajar untuk madrasah ibtidaiyah atau sekolah dasar kelas 1-3 memiliki ukuran tertentu yaitu (1) A4 dengan bentuk huruf vertikal atau landscape, A5 dengan bentuk huruf vertikal atau landscape, atau B5 dengan bentuk huruf vertikal atau landscape. Berdasarkan pendapat tersebut, ukuran bahan ajar untuk kelas III SD/MI tidak hanya A4 saja, melainkan bisa menggunakan ukuran A5 atau B5 yang memiliki ukuran lebih praktis. Berikut adalah hasil pengisian angket analisis kebutuhan siswa kelas III B MI Qomarul Hidayah Trenggalek terkait bahan ajar yang berukuran praktis.

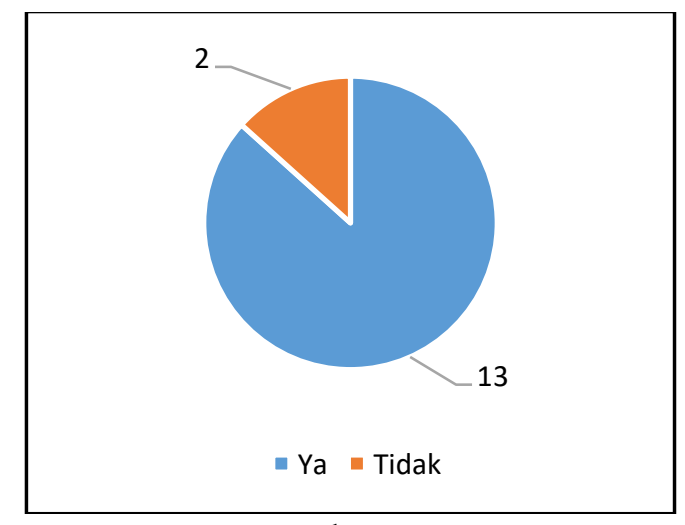

Gambar C.1

Hasil Pengisian Angket Analisis Kebutuhan Terkait Bahan Ajar yang Berukuran Praktis

Data hasil kuantitatif menunjukkan bahwa 13 siswa menjawab "Ya" dan 2 siswa menjawab "Tidak". Jika diubah menjadi bentuk persentase sesuai dengan rumus Bungin (dalam Munggaran, 2012, p. 72-73) diperoleh hasil yaitu 86,7\% siswa menjawab 
"Ya". Dengan demikian dapat disimpulkan bahwa siswa kelas III B MI Qomarul Hidayah Trenggalek membutuhkan bahan ajar yang berukuran praktis.

2. Siswa kelas III B MI Qomarul Hidayah Trenggalek membutuhkan sumber belajar tambahan tentang bangun datar dan sifat-sifatnya yang materinya lebih lengkap

Bahan ajar yang digunakan siswa kelas III B MI Qomarul Hidayah Trenggalek adalah buku tematik, dimana berdasarkan hasil wawancara yang telah dilakukan materi terkait bangun datar dan sifat-sifatnya pada buku tematik yang digunakan siswa sebagai sumber belajar masih kurang lengkap. Sebagai sumber belajar seharusnya materi di dalam bahan ajar disusun dengan lengkap. Hal ini sejalan dengan pendapat Furqon (dalam Nurdyansyah, 2018) bahwa beberapa kriteria bahan ajar yang baik yaitu materi yang diulas harus benar, lengkap, dan aktual. Dari hasil dokumentasi yang telah dilakukan juga diketahui bahwa masih terdapat kesenjangan antara materi bangun datar dan sifat-sifatnya pada silabus dengan materi bangun datar dan sifat-sifatnya pada bahan ajar buku tematik yang digunakan siswa. Padahal menurut Sagala (2008, p. 11) silabus digunakan sebagai landasan pelaksanaan dan pengembangan pembelajaran. Dari hasil wawancara dan hasil dokumentasi tersebut maka dilakukan analisis kebutuhan bahan ajar terkait materi bangun datar dan sifat-sifatnya yang materinya lebih lengkap. Berikut adalah hasil pengisian angket analisis kebutuhan siswa kelas III B MI Qomarul Hidayah Trenggalek terkait sumber belajar tambahan tentang bangun datar dan sifat-sifatnya yang materinya lebih lengkap.

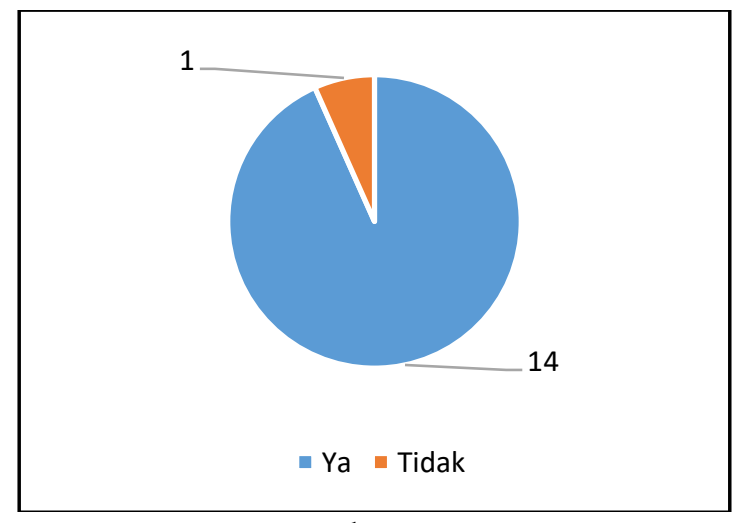

Gambar C. 2

Hasil Pengisian Angket Analisis Kebutuhan Terkait Sumber Belajar Tambahan Tentang Bangun Datar dan Sifat-sifatnya yang Materinya Lebih Lengkap

Data hasil kuantitatif menunjukkan bahwa 14 siswa menjawab "Ya" dan 1 siswa menjawab "Tidak". Jika diubah menjadi bentuk persentase sesuai dengan rumus Bungin (dalam Munggaran, 2012, p. 72-73) diperoleh hasil yaitu 93,3\% siswa menjawab "Ya". Dengan demikian dapat disimpulkan bahwa siswa kelas III B MI Qomarul Hidayah Trenggalek membutuhkan sumber belajar tambahan tentang bangun datar dan sifat-sifatnya yang materinya lebih lengkap.

3. Siswa kelas III B MI Qomarul Hidayah Trenggalek membutuhkan latihan soal untuk mengukur pemahaman terhadap materi bangun datar dan sifat-sifatnya

Bahan ajar yang digunakan siswa kelas III B MI Qomarul Hidayah Trenggalek adalah buku tematik. Buku tematik adalah buku pedoman siswa dalam proses pembelajaran yang berisi materi, kegiatan penyelidikan sesuai konsep, informasi- 


\section{MADRASAH}

Jurnal Pendidikan dan Pembelajaran Dasar

informasi, dan berbagai macam contoh penerapan matematika dalam kehidupan sehari-hari (Trianto (dalam Kholil \& Usriyah, 2020, p. 56)). Dengan demikian di dalam buku tematik tidak terdapat latihan soal. Padahal dengan latihan soal dapat diketahui tingkat pemahaman siswa terhadap materi yang diajarkan. Berikut adalah hasil pengisian angket analisis kebutuhan siswa kelas III B MI Qomarul Hidayah Trenggalek terkait adanya latihan soal untuk mengukur pemahaman terhadap materi bangun datar dan sifat-sifatnya.

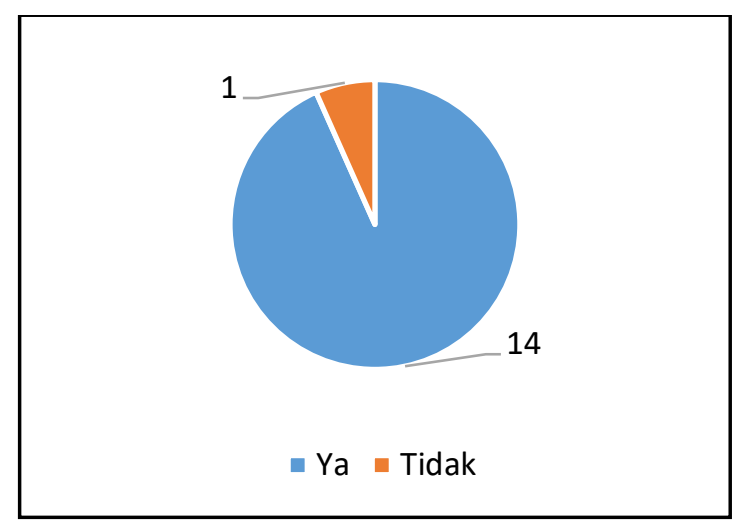

Gambar C. 3

Hasil Pengisian Angket Analisis Kebutuhan Terkait Adanya Latihan Soal untuk Mengukur Pemahaman Terhadap Materi Bangun Datar dan Sifat-sifatnya

Data hasil kuantitatif menunjukkan bahwa 14 siswa menjawab "Ya" dan 1 siswa menjawab "Tidak". Jika diubah menjadi bentuk persentase sesuai dengan rumus Bungin (dalam Munggaran, 2012, p. 72-73) diperoleh hasil yaitu 93,3\% siswa menjawab "Ya". Dengan demikian dapat disimpulkan bahwa siswa kelas III B MI Qomarul Hidayah Trenggalek membutuhkan latihan soal untuk mengukur pemahaman terhadap materi bangun datar dan sifat-sifatnya.

4. Siswa kelas III B MI Qomarul Hidayah Trenggalek membutuhkan bahan ajar yang bisa dipakai untuk belajar mandiri

Siswa kelas III B MI Qomarul Hidayah Trenggalek memiliki kemampuan yang berbeda-beda. Ada yang memiliki kemampuan tinggi, sedang, dan rendah. Oleh karena itu perlu adanya bahan ajar yang bisa dipakai untuk belajar mandiri sesuai kemampuan yang dimiliki siswa baik yang berkemampuan tinggi, sedang, maupun rendah. Menurut Hernawan et al. (2012, p. 2) bahan ajar juga bisa dipakai untuk belajar mandiri apabila bahan ajar tersebut disusun secara lengkap. Bahan ajar sendiri memiliki banyak ragam. Menurut Prastowo, (2016, p. 297) bahan ajar terdiri dari handout, buku, modul, LKS, brosur, leaflet, wallchart, foto/gambar, dan model/maket dimana setiap jenis bahan ajar tersebut memiliki komponen yang berbeda-beda. Berikut adalah hasil pengisian angket analisis kebutuhan siswa kelas III B MI Qomarul Hidayah Trenggalek terkait bahan ajar yang bisa dipakai untuk belajar mandiri. 


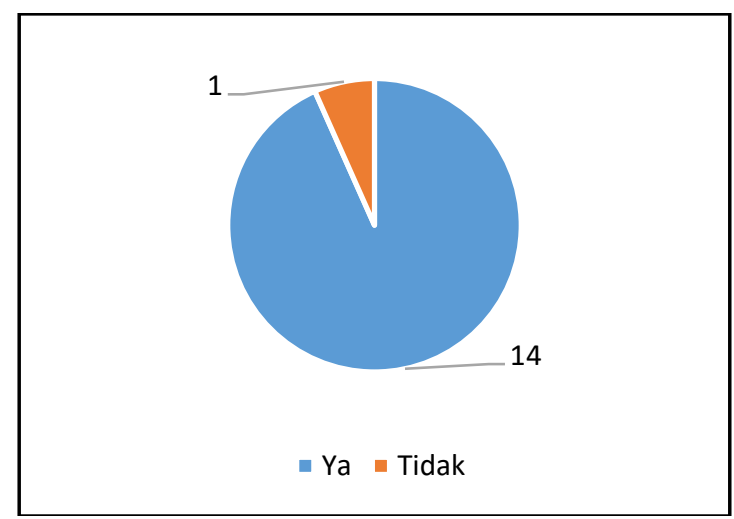

Gambar C. 4

Hasil Pengisian Angket Analisis Kebutuhan Terkait Bahan Ajar yang Bisa Dipakai untuk Belajar Mandiri

Data hasil kuantitatif menunjukkan bahwa 14 siswa menjawab "Ya" dan 1 siswa menjawab "Tidak". Jika diubah menjadi bentuk persentase sesuai dengan rumus Bungin (dalam Munggaran, 2012, p. 72-73) diperoleh hasil yaitu 93,3\% siswa menjawab "Ya". Dengan demikian dapat disimpulkan bahwa siswa kelas III B MI Qomarul Hidayah Trenggalek membutuhkan bahan ajar yang bisa dipakai untuk belajar mandiri.

5. Siswa kelas III B MI Qomarul Hidayah Trenggalek setuju jika dikembangkan booklet bangun datar dan sifat-sifatnya yang memiliki ukuran praktis, materi lebih lengkap, terdapat latihan soal, dan bisa dipakai untuk belajar mandiri

Pertanyaan nomor 5 pada angket analisis kebutuhan ini berisi apakah siswa kelas III B MI Qomarul Hidayah Trenggalek setuju jika dikembangkan booklet bangun datar dan sifat-sifatnya yang memiliki ukuran praktis, materi lebih lengkap, terdapat latihan soal, dan bisa dipakai untuk belajar mandiri. Pertanyaan tersebut merupakan penegasan bahwa bahan ajar yang dipilih dimana memiliki ukuran praktis, memuat materi lebih lengkap, memuat latihan soal, dan bisa dipakai untuk belajar mandiri yang sesuai dengan pertanyaan nomor 1 sampai nomor 4 pada angket analisis kebutuhan yang telah dipaparkan sebelumnya adalah bahan ajar jenis buku yaitu berupa booklet.

Pemilihan booklet tersebut dikarenakan booklet memiliki ukuran yang praktis, menarik, dan bisa dipakai untuk belajar mandiri. Hal ini sesuai dengan pendapat Ewles (dalam Hapsari, 2013) bahwa salah satu keunggulan booklet yaitu bisa dipakai untuk belajar mandiri. Arsyad (dalam Utami, 2018, p. 33) juga menyebutkan bahwa salah satu kelebihan booklet sebagai media cetak yaitu dapat menambah ketertarikan serta memudahkan pemahaman pesan karena terdiri dari tulisan dan gambar. Dengan daya tarik yang dimiliki booklet maka siswa akan lebih tertarik dan merasa tidak bosan ketika mempelajari matematika. Karena matematika menurut Yuniawatika et al. (2016, p. 236) adalah sesuatu yang membosankan dan menakutkan sehingga sebagian besar siswa tidak menyukai bahkan benci dengan matematika. Booklet juga memiliki ukuran praktis karena menurut French (dalam Utami, 2018, p.40) penggunaan kertas A5 direkomendasikan untuk membuat booklet.

Selain memiliki ukuran yang praktis, menarik, dan bisa dipakai untuk belajar mandiri, booklet juga bisa memuat materi yang lebih lengkap dan memuat latihan soal dikarenakan booklet juga bisa dikatakan sebagai bahan ajar jenis buku. Hal tersebut sesuai dengan pendapat Prastowo (2016, p. 297) bahwa bahan ajar jenis buku terdiri 


\section{MADRASAH}

Jurnal Pendidikan dan Pembelajaran Dasar

dari lima komponen yaitu (1) judul; (2) kompetensi dasar/materi pokok; (3) informasi pendukung; (4) latihan; dan (5) penilaian. Berikut adalah hasil pengisian angket analisis kebutuhan siswa kelas III B MI Qomarul Hidayah Trenggalek terkait setuju tidaknya jika dikembangkan booklet bangun datar dan sifat-sifatnya yang memiliki ukuran praktis, materi lebih lengkap, terdapat latihan soal, dan bisa dipakai untuk belajar mandiri.

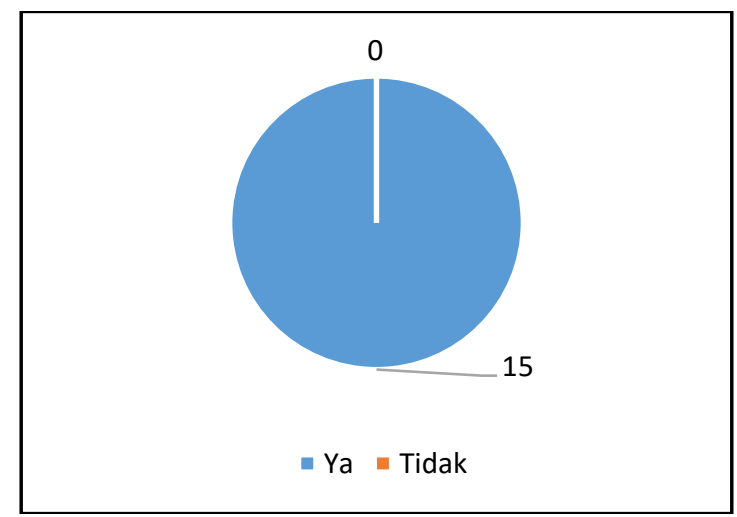

Gambar C. 5

Hasil Pengisian Angket Analisis Kebutuhan Terkait Setuju Tidaknya Jika Dikembangkan Booklet Bangun Datar dan Sifat-sifatnya yang Memiliki Ukuran Praktis, Materi Lebih Lengkap, Terdapat Latihan Soal, dan Bisa Dipakai untuk Belajar Mandiri

Data hasil kuantitatif menunjukkan bahwa 15 siswa menjawab "Ya" dan tidak ada siswa yang menjawab "Tidak". Jika diubah menjadi bentuk persentase sesuai dengan rumus Bungin (dalam Munggaran, 2012, p. 72-73) diperoleh hasil yaitu 100\% siswa menjawab "Ya". Dengan demikian dapat disimpulkan bahwa siswa kelas III B MI Qomarul Hidayah Trenggalek setuju jika dikembangkan booklet bangun datar dan sifatsifatnya yang memiliki ukuran praktis, materi lebih lengkap, terdapat latihan soal, dan bisa dipakai untuk belajar mandiri.

\section{KESIMPULAN}

Penelitian ini bertujuan untuk mengemukakan hasil analisis kebutuhan bahan ajar booklet bangun datar dan sifat-sifatnya siswa kelas III B MI Qomarul Hidayah Trenggalek. Hasil pengisian angket analisis kebutuhan menunjukkan bahwa siswa kelas III B MI Qomarul Hidayah Trenggalek setuju jika dikembangkan booklet bangun datar dan sifat-sifatnya. Booklet yang dikembangkan disesuaikan dengan hasil wawancara dengan guru kelas III B MI Qomarul Hidayah Trenggalek, hasil dokumentasi, serta hasil pengisian angket analisis kebutuhan siswa kelas III B MI Qomarul Hidayah Trenggalek yaitu: (1) memiliki ukuran yang praktis; (2) materi lebih lengkap; (3) terdapat latihan soal; dan (4) bisa dipakai untuk belajar mandiri. Hasil dari penelitian ini masih perlu ditindak lanjuti yaitu dengan mengembangkan booklet bangun datar dan sifat-sifatnya yang memiliki ukuran praktis, materi lebih lengkap, terdapat latihan soal, dan bisa dipakai untuk belajar mandiri. Setelah itu divalidasikan kepada ahli dan guru, diuji cobakan kepada siswa, dan kemudian diproduksi masal. 


\section{REFERENSI}

Bagaray, F. E. K., Wowor, V. N. S., \& Mintjelungan, C. N. (2016). Perbedaan Efektivitas DHE dengan Media Booklet dan Media Flip Chart terhadap Peningkatan Pengetahuan Kesehatan Gigi dan Mulut Siswa SDN 126 Manado. Jurnal e-GiGi, 4(2),

76-82.

https:/ / ejournal.unsrat.ac.id/index.php/egigi/article/view/13487/13017

Bly, R. (2009). Money-Making Writing Jobs. United States of America: Sourcebooks, Inc.

Etika, S., Dariyo, A., \& Zahra, R. P. (2017). Persepsi Gaya Mengajar Guru dan Prestasi

Belajar Matematika pada Murid SD di Jakarta. Journal An-nafs, 2(2), 169-186. ejournal.iai-tribakti.ac.id

Fanny, A. M., \& Suardiman, S. P. (2013). Pengembangan Multimedia Interaktif untuk Mata Pelajaran Ilmu Pengetahuan Sosial (IPS) Sekolah Dasar Kelas V. Jurnal Prima Edukasia, 1(1), 1-9. journal.uny.ac.id

Farkhana, Priyono, B., \& Setiati, N. (2017). Penggunaan Model Think Talk Write (TTW) dengan Media Booklet pada Hasil Belajar Siswa Materi Invertebrata di SMA Negeri 2 Ungaran. Journal of Biology Education, 5(1), 56-62. http:/ / journal.unnes.ac.id/sju/index.php/ ujbe

French, C. (2013). How to Write a Successful How-to Booklet. England UK: The Endless Bookcase.

Gemilang, R., \& Christiana, E. (2016). Pengembangan Booklet sebagai Media Layanan Informasi untuk Pamahaman Gaya Hidup Hedonisme Siswa Kelas XI di SMAN 3 $\begin{array}{lllll}\text { Sidoarjo. Jurnal } & \text { BK }\end{array}$ https://jurnalmahasiswa.unesa.ac.id/index.php/jurnal-bkunesa/article/view/15890/14411

Hapsari, C. M. (2013). Efektivitas Komunikasi Media Booklet "Anak Alami" sebagai Media Penyampai Pesan Gentle Birthing Service. Jurnal E-Komunikasi, 1(3), 264-275. publication.petra.ac.id/index.php/ilmu-komunikasi/article/view/940/840

Hernawan, A. H., Permasih, H., \& Dewi, L. (2012, February 2003). Pengembangan Bahan Ajar. Bandung: Direktorat UPI. Retrieved from file.upi.edu

Kholil, M., \& Usriyah, L. (2020). Pengembangan Buku Ajar Matematika Terintegrasi Nilai-nilai Keislaman dalam Penanaman Karakter Siswa Madrasah Ibtidaiyah. Madrasah: Jurnal Pendidikan dan Pembelajaran Dasar, 12(1), 52-62. http:/ /103.17.76.13/index.php/madrasah/article/view/7442/pdf

Munggaran, R. (2012, February 23). Pemanfaatan Open Source Software Pendidikan oleh Mahasiswa dalam Rangka Implementasi Undang-Undang No. 19 Tahun 2002 Tentang Hak Cipta Intelectual Property Rights. Bandung: Universitas Pendidikan Indonesia. Retrieved from repository.upi.edu

Nasrulloh, I., \& Ismail, A. (2017). Analisis Kebutuhan Pembelajaran Berbasis ICT. Jurnal PETIK, 3(1), 28-32. journal.institutpendidikan.ac.id

Nurdyansyah, N. (2018, February 23). Pengembangan Bahan Ajar Modul Ilmu Pengetahuan Alam bagi Siswa Kelas IV Sekolah Dasar. Sidoarjo: Universitas Muhammadiyah Sidoarjo. Retrieved from http://eprints.umsida.ac.id/1607/

Prastowo, A. (2016). Pengembangan Bahan Ajar Tematik Tinjauan Teoritis dan Praktis. Jakarta: Kencana.

Rahmatih, A. N., Yuniastuti, A., \& Susanti, R. (2017). Pengembangan Booklet Berdasarkan Kajian Potensi dan Masalah Lokal sebagai Suplemen Bahan Ajar 


\section{MADRASAH}

Jurnal Pendidikan dan Pembelajaran Dasar

p ISSN: 1979-5599 | e ISSN: 2502-194X

P a g e | 117

SMK Pertanian. Journal of Innovative Science Education, 6(2), 162-169. http://journal.unnes.ac.id/sju/index.php/jise

Rahmawati, F. (2019). Pengembangan Booklet Terintegrasi Media Online sebagai Media Pembelajaran pada Pelajaran Marketing Kompetensi Dasar Menganalisis Pasar Kelas X Bisnis di SMK Negeri 2 Buduran. Jurnal Pendidikan Tata Niaga (PTN), 7(2), 456-460. jurnalmahasiswa.unesa.ac.id

Sagala, S. (2008). Silabus Sebagai Landasan Pelaksanaan dan Pengembangan Pembelajaran bagi Guru yang Profesional. Jurnal Tabularasa PPS Unimed, 5(1), 1122. digilib.unimed.ac.id

Siska, Y. (2015). Analisis Kebutuhan Bahan Ajar Sejarah Lokal Lampung untuk Sekolah $\begin{array}{llll}\text { Dasar. Mimbar Sekolah 199-211. } & \text { Dasar, }\end{array}$ http://journal.upi.edu/index.php/mimbar

Sitepu, B. P. (2015). Penulisan Buku Teks Pelajaran. Bandung: PT Remaja Rosdakarya.

Sugiyono. (2011). Metode Penelitian Pendidikan Pendekatan Kuantitatif, Kualitatif, dan RED. Bandung: Alfabeta.

Suyitno, I. (2017). Pengembangan Bahan Ajar Bahasa Indonesia untuk Penutur Asing (BIPA) Berdasarkan Hasil Analisis Kebutuhan Belajar. WACANA, 9(1), 62-78. brill.com

Utami, W. F. (2018, February 23). Pengembangan Media Booklet Teknik Kaitan untuk Siswa Kelas X SMKN 1 Saptosari Gunung Kidul. Yogyakarta: Universitas Negeri Yogyakarta. Retrieved from https:/ / eprints.uny.ac.id/55023/

Utomo, M. A. W. (2016, February 23). Pengembangan Bahan Ajar Model Booklet Materi Sumber Daya Hutan Kelas VII. Surakarta: Universitas Muhammadiyah Surakarta. Retrieved from eprints.ums.ac.id

Wulandari, F. (2019). Analisis Kesiapsiagaan Siswa dalam Menghadapi Bencana Kekeringan Melalui Media Booklet. Jurnal Tarbawi: Jurnal Ilmu Pendidikan, 15(1), 6574. ejournal.iainkerinci.ac.id/index.php/tarbawi/article/view/346/267

Yuliana, Muldayanti, N. D., \& Kahar A. P. (2019). Studi Komparasi Media Pembelajaran Booklet Berbasis Sikap Konservasi dan Media Gambar Terhadap Hasil Belajar pada Materi Keanekaragaman Hayati di SMA/MA Kecamatan Rasau Jaya. Jurnal Bioeducation, $6(2)$, 50-54. openjurnal.unmuhpnk.ac.id/index.php/bioed/article/view/1179/pdf

Yuniawatika, Yuspriyati, D. N., Sani, I., \& Febriyanti. (2016). Perkembangan Pendidikan Matematika Realistik Indonesia (PMRI) di LPTK Bandung Raya. Mosharafa: Jurnal Pendidikan Matematika STKIP Garut, 5(3), 235-246. e.mosharafa.org 